\title{
MANAGING MULTIPLE SOURCES OF COMPETITIVE ADVANTAGE IN A COMPLEX COMPETITIVE ENVIRONMENT
}

\section{Alexandre Howard Henry Lapersonne}

Doctorate Student Candidate, Manchester Business School, United Kingdom alexandre.lapersonne@postgrad.manchester.ac.uk (United Kingdom)

\section{ABSTRACT}

The aim of this article is to review the literature on the topic of sustained and temporary competitive advantage creation, specifically in dynamic markets, and to propose further research possibilities. After having analyzed the main trends and scholars' works on the subject, it was concluded that a firm which has been experiencing erosion of its core sources of economic rent generation, should have diversified its strategy portfolio in a search for new sources of competitive advantage, ones that could compensate for the decline of profits provoked by intensive competitive environments. This review concludes with the hypothesis that firms who have decided to manage complex competitive environments should have developed a multiple strategies framework approach. As a result of the literature review, we propose a reconceptualization of the construct hypercompetition adding the concept of market complexity, which allowed us to raise important further research possibilities.

Keywords: Competitive strategy. Hypercompetition. Complex strategy. Competitive advantage. Dynamic markets.

\section{RESUMO}

O objetivo deste artigo é revisar a literatura sobre o tema criação de vantagem competitiva sustentável e temporária, especificamente em 
mercados dinâmicos, e de propor novas possibilidades de pesquisa. Após analise das principais tendências e de obras de estudiosos sobre o assunto, concluiu-se que a deterioração das principais fontes de geração de renda econômica de uma empresa deveria diversificar sua carteira de estratégia em busca de novas fontes de vantagem competitiva que poderiam compensar o declínio dos lucros provocados por ambientes intensamente competitivos. Esta avaliação conclui com a hipótese de que as empresas que decidiram gerenciar ambientes competitivos complexos devem desenvolver uma abordagem de múltiplas estratégias. Como resultado da revisão da literatura, propomos uma reconceituação da do constructo de hipercompetitividade adicionando o conceito de complexidade do mercado, o que nos permitiu levantar importantes novas possibilidades de pesquisa.

Palavras-chave: Estratégia Competitiva, Hipercompetição, Estratégias complexas, Vantagem Competitiva, Dinâmica de Mercados. 


\section{INTRODUCTION}

The fact that we have entered turbulent times has been a central theme in the recent strategy literature. Turbulent environments are commonly described by increased competitive intensity, disruptive changes in the industry structure, volatility of demand, and unpredictability of customer behavior, alongside instability of economic, social and political factors. In these complex competitive environments, firms have been forced to adapt to survive and to maintain their financial performance. In such context, the adoption of traditional approaches to strategy such as the Porter's Model and the RBV framework, which assumes a relatively stable world, have been questioned by the emergence of new approaches such as dynamic capabilities, new 7's framework, and temporary competitive advantage.

In this literature review we decided to focus on the last trends in the field of strategy that involve the concepts of hypercompetition and temporary competitive advantage to propose further research possibilities. Firstly we revisited the main concepts and constructs of the traditional approaches of sustained competitive advantage and describe the relationship that exists of theses approaches with characteristics of more stable and simple competitive environments. Than we demonstrate why such traditional approaches of sustained competitive advantage are not suitable in more dynamic and highvelocity environments. Than we elucidate the characteristics of hypercompetitive market and explore is relationship with the construct of temporary competitive advantage. The investigation of the characteristics of the nature of competition is fundamental to understand firm's competitive advantage idiosyncrasies, for this we separated a chapter to revisit the root of the concept of competition, which allowed exploring new possibilities. 


\section{THE TRADITIONAL APPROACHES OF SUSTAINED COMPETITIVE ADVANTAGE}

The idea that a firm could sustain superior economic rent over competitors is a central subject in the competitive strategy literature. One of the most established approaches to competitive advantage comes from the Industrial Organization perspective (IO), popularly represented by Porter's competitive strategy framework (1980, 1981, 1985, 1990). The competitive strategy framework defines that a firm can generate and sustain competitive advantage by strategically choosing a privileged position in the industry, which allows a superior economic rent generation.

This approach to competition established a significant break with the more traditional IO scholars who used to defend the economic model of competition where the firm's choice and action has little influence on its performance and environment, and where the firm's rent generation is mostly determined by industry (Bain, 1956, 1968; Mason, 1939).

Conversely, Porter defends that a firm is capable of influencing its performance, if it is capable of reading the underlying characteristics of its industry and strategically choose a favorable position before other competitors. Five main "forces" represent these industry idiosyncrasies: barriers to entry, bargaining power of suppliers and buyers, product substitute and level of rivalry (Porter, 1980).

A favorable position would be one where entry barriers are high; bargaining powers of suppliers and buyers are low; threats of product substitute are irrelevant and levels of rivalry are low. Then the competitive advantage could come from two different rent generation mechanisms: a differentiation approach where the firm by undertaking unique activities, offers a value that sustains a superior margin by higher price, or by choosing a cost approach where by offering equivalent activities at a lower cost, offers value that sustains a superior margin by lower price (superior margin by volume) or by equating price (superior margin by lower cost) (Porter, 1996).

Once established in such a condition, the firm will be in a type of particular monopolist position as it will be alone in enjoying a specific market segment. The competitive advantage comes by virtue of the fact that the position of the firm is 
exclusive, special, and particular and cannot be easily exploited by other competitors as natural barriers provided by the industry structure protect it. In such a condition it is said that the firm has a superior rent generation over the industry average, characterized as a competitive advantage. This competitive advantage will be considered sustainable as long as the configuration of the industry structure that favors the firm remains unchanged (Porter, 1991). Consequently, industry structure stability is fundamental for a firm that has based their strategy and rent generation on such an approach.

The industry will attract new competitors if the rent generation opportunities are superior to the average interest rate return (Porter, 1980). Thus these new entrants will have to lead with high initial investments, risks, and higher costs and offer a lower price to enter the market. Established firms could make it difficult for the entry of new entrants by the use of the economy of scale effect, or by previous marketing investment that had resulted in customer loyalty, by product differentiation or by distribution channel exclusivity.

New entrants could try to outline insurmountable barriers, creating new products, introducing technological innovation or influencing customer preference. Also, a new entrant could decide to merge or acquire an established competitor to enter the market. The competition will increase until new entrants decide that the market is not sufficiently attractive in terms of returns compared to the investment, effort and risk involved (Porter, 1980).

If on one hand the competitive strategy framework emphasizes the importance of industry idiosyncrasy for the sustainability of competitive advantage, then on the other hand, the Resource based view perspective (RBV), approaches the subject from a completely opposite angle. In the RBV perspective, the superior rent generation comes from inside the firm, and not from an industry structure effect (Wernerfelt, 1984). This is the resources and capabilities that the firm acquires, and mainly develops internally that will be responsible for the firm's superior rent generation (Diericx \& Cool, 1989). This competitive advantage based on a firm's valuable and rare assets is sustained by two principles: resources heterogeneity and imperfect mobility (Barney, 1991; Peteraf, 1993; Amit \& Schoemaker, 1993). In fact, Barney (1991) demonstrates that if firms have access and can acquire or develop exactly the same resources and capabilities then it is not possible for any one of these firms to generate 
superior rent over the other. Consequently, in an industry where a firm's resources are homogeneous and highly mobile, sustained competitive advantage is simply not possible (Barney, 1991). Therefore, the resources configuration that sustains the competitive advantage of the firm should present four main attributes. The resources frame needs to be valuable, rare, inimitable and not substitutable (VRIN). The rareness ensures that other firms would not have easy access to the same valuable assets. The inimitability attributes guarantee that competitors will not easily reproduce the same resources and capabilities. Imperfectly imitable resources could be the result of unique historical conditions, causal ambiguity or social complexity of the firms (Lippman \& Rumelt, 1982; Black \& Boal, 1994; King, 2007).

Also, to guarantee the effect of competitive advantage, competitors should not be able to substitute a strategic firm's assets by resources or configurations of resources with equivalent values. The competitive advantage will be sustainable as long as the VRIN attributes of the resources remain valid.

Although the RBV took a firm inside-out approach for the generation of competitive advantage, and that Porter's framework took a firm outside-in, the two theories are much more complementary than exclusionary. In fact, Porter (1991) sustains that competitive advantage could come only if the firm's positioning is based on a unique valuable chain of activities. Such activities imply intrinsically the uses of valuable and distinct resources and capabilities. On the other hand, the firm could not remain unique in its strategy on a resource approach. It will be inevitable to consider the nature of the industry structure and competitors positioning to evaluate if the resources chosen will be valuable, and if they have not already been implemented by other competitors (Grant, 1991; Barney \& Zajac, 1994).

Despite the fact that the competitive strategy framework and RBV perspective emphasize different aspects of a firm's generation of competitive advantage, they are so related that many authors consider both a unique framework (Wernerfelt, 1984; Mahoney \& Pandian, 1992; Amit \& Schoemaker, 1993; Spanos \& Lioukas, 2001). The main aspect that unifies the Porter framework and the RBV perspective is the fact that the source of competitive advantage is considered stable and durable, that, because industry forces characteristics to remain unchanged or because the firm has developed a strategic asset that once established is difficult to change (Conner, 1991). 
Spanos \& Lioukas (2001) in a study of the similarities and differences of the two theory frameworks conclude that the rent creation mechanism comes from different logic, as Porter's framework is monopoly type rent creation (Bain type IO) and that the resource based perspective is an efficiency type rent creation. This is exactly the complementary aspect that allows integrating these two approaches in a unique framework that allows firms to obtain sustained competitive advantage.

\section{HYPERCOMPETITIVE ENVIRONMENTS AND TEMPORARY COMPETITIVE ADVANTAGE}

A completely different approach came from the idea of hypercompetition. Hypercompetitive environments are characterized by high-velocity and a high level of rivalry. Industry structures are ambiguous, players are shifting and boundaries are blurring and converging. Demand evaporates, and competitors could become engaged in a race of fast rounds of innovation-imitation (D'Aveni 1994, 1999, 2010; D’Aveni, Dagnino \& Smith, 2010; Eisenhardt \& Martin, 2000; Grimm, Lee \& Smith, 2006; Pacheco de Almeida, 2010).

Even though the exact origin of such business environments is unclear, many authors agree that recent phenomenon such as globalization, technology dissemination, regulation, disintegration and demand rarefication could be one of the causes of such accelerated disruptive and unstable business environments. Harvey, Novicevic and Kiessling (2001), have classified at least four main drivers of hypercompetition associated to the globalization phenomenon. There are macroeconomic drivers such as availability of key production factors, increased flows of cross border technology transfers, and irregular intra-country fluctuations in exchange rates; political drivers such as removal of barriers to international trade, development of regional trading blocks and reduced protection of intellectual property rights; technology drivers such as declining cost of communication, computation and transportation, shortened product and technology life-cycles, dissemination of knowledge-based industries, and increased globalization of product offerings; finally, organizational drivers characterized by a global industry effect of resources commodification, consolidation of competitors and development of network organizations. 
Some scholars have expressed doubt if such hypercompetitive business environments already exist (McNamara, Vaaler \& Devers, 2003), others have restricted hypercompetition to particular cases (Porter, 1996). However, the importance that the subject has been attracting in the strategic literature and the evidence brought by recent empirical research (Wiggins \& Ruefli, 2005), highlights the relevance and solidity of the theme for the competitive strategy field and the study of competitive advantage.

In such high-velocity and disruptive business environments, traditional approaches such as Porter's competitive strategy framework are difficult to apply, because the dynamic change of industry is so important that it is problematic to clearly define the boundaries between rivals, suppliers and customers and to establish a stable and durable position. Take as an example the case of the tablet and smartphone industries where the two most important players, Apple and Samsung, are at the same time main rivals and main partners of each other. Take also the case of Nokia, Google and Apple, who a few years ago were not competitors as they were in completely different industries.

Some scholars argue that hypercompetition could be a particular situation of Porter's five forces, where barriers to entry are low, rivalry high, and bargaining power of buyers and suppliers high (D'Aveni, 2010). In such a situation, firms lose their competitive advantage as anyone could enter the market to offer an equivalent product or service for an equivalent price (Williams, 1992). Strong rivalry, associated to the high bargaining power of buyers and suppliers, leads to a collective erosion of profits, resulting in a commoditized market that will stabilize with minimum profit equilibrium. This is what is commonly called a perfect competition situation. D'Aveni (1999) argues that this situation of perfect competition will never happen, as the pressure of rivalry will trigger an innovative disruption that will change the rules of competition. In fact, in the pursuit of undermining competitors' competitive advantage to avoid the commodity trap (D'Aveni, 2010), firms explore new markets; launch new breakthrough products in search for differentiation and new sources of competitive advantage to change the competitive game, attaining temporary advantage that will last until other competitors outmaneuver it. In such highly dynamic situations, markets never come to full maturity and stay in a permanent disequilibrium situation, remembering the Schumpeterian creative destruction process (Schumpeter, 1942; D'Aveni, 1999). 
It is also very difficult to maintain a strategy based on a resource-based approach in a hypercompetitive environment. This is because the development of sustained competitive advantage based on resources requires elements that are very difficult to find in a hypercompetitive environment. Resources that have the VRIN properties require a sequence of logical and continuous investments. The VRIN attributes come with the development of unique resources that require a firm's unique historical condition, social complexity and causal ambiguity. Unfortunately, in a hypercompetitive environment the firm will not have the market stability opportunities to develop such valuable and unique resources. The disruptive nature of hypercompetition will invalidate the firm's resources strategy before the necessary maturity that leads to competitive advantage and generate superior rent. Worse still is for the firm that had already developed solid resources' configurations: once its business environment turns to hypercompetition, these solid foundations that used to bring sustained competitive advantage will unveil as the main handicaps to react in an abrupt and disruptive competitive situation. In fact, if resources with VRIN attributes are costly and time consuming to develop, once established, it is very difficult to change them. If in a stable competitive environment unique historical conditions, causal ambiguity and social complexity of a firm's resources development impose serious constraints to imitation, then conversely in a hypercompetitive environment, the pace of change invalidates their values, transforming the barriers to imitation in a limited way for adaptation. On the other hand, hypercompetition requires resources flexibility and adaptation, therefore, in such an environment resources are much more homogeneous and mobile, invalidating the basic assumptions of sustained competitive advantage of the Resource-based perspective.

\section{THE RBV RESPONSE TO DYNAMIC ENVIRONMENTS}

In a response to these new requirements, RBV proponents have introduced the concept of dynamic capabilities. Dynamic capabilities are a firm's processes, strategic routines that permit them to alter sets of resources, integrating, reconfiguring, acquiring and shedding, resulting in new resources' combinations that enable new sources of competitive advantage (Teece, Pisano \& 
Shuen, 1997; Helfat, 2000; Winter, 2003). These new resources' reconfigurations have been used in response to market change and even to shift market competition. Dynamic capabilities have been defended to present the VRIN attributes, therefore, leading to sustained competitive advantage.

Besides that, many authors defend that dynamic capabilities have returned the sources of sustained competitive advantage to RBV (Teece, Pisano \& Suen, 1997), some other authors argue that dynamic capabilities are not sufficient condition to sustain competitive advantage (Eisenhardt \& Martin, 2000). This is mainly because of their equifinality and commonality nature. In fact, dynamic capabilities are routines to modify routines, or more popularly called "best practices". Best practices could be applied in different ways and take different paths to results in equivalent outcomes, hence their equifinality nature. Dynamic capabilities also present a commonality nature, because best practices are easily substitutable or interchangeable by other best practices, independently of the firm. Therefore, dynamic capabilities could be valuable, and also rare, as all firms do not easily acquire them, but they fail to match the non-imitable and nonsubstitutable requirements, due to their equifinality and commonality nature. As such, they could at best provide temporary advantage (Eisenhardt \& Martin, 2000).

As Eisenhardt and Martin (2000) have elucidated, depending on the level of competition in moderate dynamic markets, dynamic capabilities could be used to create sustained competitive advantage by a sequence of temporary advantage. However, the nature of sustainability would not come from the capabilities itself, but from a successful sequence of resources' configurations. Conversely, in high-velocity markets, dynamic capabilities are much more simple and improvised routines, by consequence ephemeral in nature, and can at best provide isolated and short temporary advantage, completely losing their VRIN attributes from the Resources-based heritage.

\section{UNDERSTANDING THE DIFFERENT LEVELS OF COMPETITION}

In a recent article, D'Aveni, Dagnino and Smith (2010) proclaimed that markets have entered a period where sustained competitive advantage would be so rare that it can be considered temporary competitive advantage with 
intermittent and no abnormal profit as the new pattern of rent generation. To understand this, it is necessary to distinguish different levels of competition.

Most of the hypercompetition proponents defend a classification of hypercompetitive degrees. In his famous book on Hypercompetition, D'Aveni (1994) defends four degrees of competition: Low intensity, moderate, high intensity and extreme competition. Pacheco de Almeida (2010) categorizes degrees of competition in two dimensions: innovation and imitation strategies, with two speeds: slow and fast. Eisenhardt and Martin (2000) distinguish two levels of market competition: moderately dynamic markets and high-velocity markets. In a more recent article, D'Aveni (1999) categorizes four patterns of varying market turbulence: from a stable market with very infrequent disruptive events to a total disequilibrium market state nearly reaching a chaotic situation. To simplify and integrate this different approach, a classification of three different levels of market competition is proposed: stable market, dynamic market and high-velocity market (see Figure 1 ).

\begin{tabular}{|c|c|c|c|}
\hline & STABLE MARKET & DYNAMIC MARKET & HIGH-VELOCITY MARKET \\
\hline $\begin{array}{r}\text { Competition } \\
\text { level }\end{array}$ & $\begin{array}{l}\text { Low rivalry intensity } \\
\text { Small number of players, indirect } \\
\text { competition, segmentation with } \\
\text { only one player in each segment. }\end{array}$ & $\begin{array}{c}\text { Moderate rivalry intensity } \\
\text { Several players, direct competition } \\
\text { marked with moderate innovation and } \\
\text { imitation cycle. }\end{array}$ & $\begin{array}{c}\text { High rivalry intensity } \\
\text { Many players, aggressive competition } \\
\text { marked with fast innovation and } \\
\text { imitation cycle. }\end{array}$ \\
\hline $\begin{array}{r}\text { Industry } \\
\text { structure type }\end{array}$ & $\begin{array}{l}\text { Stable and durable industry } \\
\text { structure, defined boundaries, } \\
\text { identifiable players }\end{array}$ & $\begin{array}{c}\text { Industry structure with defined } \\
\text { boundaries and identifiable players but } \\
\text { in constant change; industry change are } \\
\text { predictable }\end{array}$ & $\begin{array}{c}\text { Ambiguous industry structure, } \\
\text { blurred boundaries, ambiguous and } \\
\text { shifting players; industry change are } \\
\text { unpredictable }\end{array}$ \\
\hline $\begin{array}{r}\text { Firm Resources } \\
\text { type }\end{array}$ & $\begin{array}{l}\text { Development of valuable, rare, no } \\
\text { imitable and nonsubstitutable set of } \\
\text { resources (RBV with VRIN) }\end{array}$ & $\begin{array}{l}\text { Resources are homogeneous and } \\
\text { mobile; dynamic capabilities based on } \\
\text { complex routines are valuable and rare } \\
\text { but easily imitable and substitutable. }\end{array}$ & $\begin{array}{c}\text { Dynamic capabilities based on simple } \\
\text { improvised routines have no VRIN } \\
\text { attributes. }\end{array}$ \\
\hline $\begin{array}{r}\text { Competitive } \\
\text { advantage type }\end{array}$ & $\begin{array}{l}\text { Long-term advantage (sustained); } \\
\text { High profits }\end{array}$ & $\begin{array}{c}\text { Sequence of concatenate temporary } \\
\text { advantage; } \\
\text { Moderate profits }\end{array}$ & $\begin{array}{c}\text { Isolated and intermittent temporary } \\
\text { advantage; } \\
\text { Low profits }\end{array}$ \\
\hline $\begin{array}{l}\text { Strategy } \\
\text { approach }\end{array}$ & $\begin{array}{l}\text { Long-term planning; source of } \\
\text { competitive advantage based on } \\
\text { stable and isolated industry } \\
\text { structure features or/and } \\
\text { heterogeneous and no mobile } \\
\text { resources. }\end{array}$ & $\begin{array}{l}\text { Short-term planning; strategy based on } \\
\text { the capabilities of adapting and } \\
\text { refreshing resources configurations. }\end{array}$ & $\begin{array}{l}\text { No Strategy planning; strategy } \\
\text { maneuvering; action and reactions. }\end{array}$ \\
\hline
\end{tabular}

Low levels of competition, characterize stable markets with a small number of players, where direct competition is normally avoided. Competitors usually choose to position themselves alone in a segment. Industry structure is stable and durable with defined boundaries and identifiable players. Firms have a long-term strategy approach based on industry positioning or resources approach or a combination of the two. Competitive advantage is sustainable and provides high and durable profits. 
In dynamic markets, the level of competition is moderate to intense. Industry structure still has clear boundaries and players, but is much more dynamic and changeable than in stable markets. Despite this, market evolution is still predictable. Several players characterize competitive arenas. Competition is more direct, with several players per segment and is characterized by a moderate rate of innovation-imitation. Firms have a medium to short-term strategy approach, which is based on dynamic capabilities that provides a sequence of concatenated temporary competitive advantage.

In high-velocity markets, the level of competition is intense to extreme. Industry structure is confusing, boundaries are unclear, and players are shifting and ambiguous. Market evolution cannot be predicted linearly. Competition is extremely aggressive with many players in the same arena and depicted by a fast rate of innovation-imitation. Strategy approach relies on actions and reactions of quick market maneuverings (D'Aveni, 1994; Eisenhardt, 1989). Competitive advantages are at best temporary, intermittent and unpredictable with low or abnormal short profit generation.

According to hypercompetition proponents, stable market situations are becoming rare: it is more and more difficult for a firm to find market segments where it could be possible to sustain a durable and highly profitable position (D'Aveni, 1999; Wiggins \& Ruefli, 2005). On the other hand, other scholars argue that high-velocity markets are particular situations of some industries or particular to a specific moment of change, and that their hypercompetitive patterns could not be generalized to the entire economy (Porter, 1996; McNamara, Vaaler \& Devers, 2003). In accordance with the two extreme and contradictory points of view, it has been defended that the intermediate situation of dynamic markets, much more intensely competitive than stable markets, but moderately dynamic compared with high-velocity environments, would be the common trend.

In fact, recent empirical research demonstrated that a market munificence situation that offers a position of sustainable abnormal profit is becoming rare. (Wiggins \& Ruefli, 2005). As previously stated, globalization, technological dissemination and deregulation are some of the reasons that make markets more competitive and dynamic, and consequently less profitable in the long run (Pacheco de Almeida, 2010). However, as was demonstrated by Pacheco de Almeida (2010), that hypercompetitive markets depicted by a fast rate of 
innovation and imitation leads to erosion and time compression of competitive advantage, lowering and bringing profit near the industry mean. Firms in an industry leader position would prefer to lose their leadership due to the expensive cost of high-speed innovation.

This is in accordance with previous Porter (1980) arguments that a firm would enter or stay in a market while it remains attractive. Market attractiveness is defined by the possibility of a firm to earn a profit return higher than the median return rate of the industry. A high-velocity environment, characterized by extreme competition, could lead to a destructive situation, and motivate firms to quit markets or to avoid entering it. In such a scenario, if the market loses its attractiveness it would become less disputed and by consequence it could return to a less intense competitive situation.

In conclusion, if on the one hand, stable markets with a munificence position are becoming scarce, then alternatively, high-velocity markets could be temporary in their competitive intensity, returning to a more normal competitive situation. These conclusions could lead to a convergence to the intermediate level of competition, one of the dynamic markets characterized by dynamic capabilities with concatenate temporary competitive advantage as a dominant situation. However, these hypotheses fail to give out more empirical evidence in the strategy management literature.

\section{RE-CONCEPTUALIZING HYPERCOMPETITION WITH THE DIMENSION OF MARKET COMPLEXITY}

In practice, most firm's situations are not so simple. To avoid an aggressive competitive situation with loss of profit and in search of new sources of competitive advantage, it is common for firms to have explored and entered new markets, and developed new kinds of product portfolio (Miller, 1992, 1993; Miller \& Chen, 1996; Lumpkin \& Dess, 1995). This repertoire of strategy diversification could have lead to the management of a more complex competitive situation, with different rivals, in different types of markets, with different levels of competitive intensity.

Proponents of complex theory have argued that marketplaces and market conditions present characteristics of complex system behavior, as these are 
made up of collective chains of activities that present nonlinear patterns and unpredictable sequences and outcomes (Levy, 1994). In such complex market environments, no individual firm could determine or fully manage market conditions (Stacey, 1995). This perspective is partially in accordance with the hypercompetition perspective, as many authors recognize that hypercompetition reaches a chaotic situation level and is unpredictable in nature (D'Aveni, 1994, 1999, 2010; Eisenhardt \& Martin, 2000).

However, hypercompetition proponents, emphasis much more the speed of the pace of change of market conditions than its complexity nature in terms of components and relationship numerousness. For example, regarding the complex theory, hypercompetition proponents recognize the unpredictability nature of high velocity and dynamic markets, but they understand that this unpredictability is due to the nature of the accelerated pace of competition. This high velocity is characterized by continuous takeover maneuvering strategies, which provoke market disruption through innovation or make changes in the rules of the game (Eisenhardt, 1989; D' Aveni, 1994, 1999; Lengnick-Hall \& Wolff, 1999).

It is undeniable that nowadays marketplaces have been increasing in terms of complexity of elements and interactions such as in the number of products and service portfolios, segments and customer type preferences.

Hypercompetition proponents have indirectly recognized this complexity nature of dynamic markets when they relate that marketplaces have been increasing in terms of the number of rivals and products offered. Also, the unpredictable industry convergence and blurring boundaries depicted by hypercompetition proponents is very similar to non-linear system behavior and emergence phenomenon described by complexity theory proponents.

Therefore, to be more precise, hypercompetition markets should be not only measured in terms of the speed of change, but also in terms of components complexity. This approach is in accordance to the Chakravarthy (1997) strategy approach.

The definition of complexity used here is the one established by Simon (1962), where complexity is defined in terms of the numerousness of components and their inter-relationships. Therefore, a two dimensional matrix with four situations that characterize the nature of market competition is proposed as: simple market with stability, complex market with stability, simple market with high velocity and complex market with high velocity (see Figure 2). 


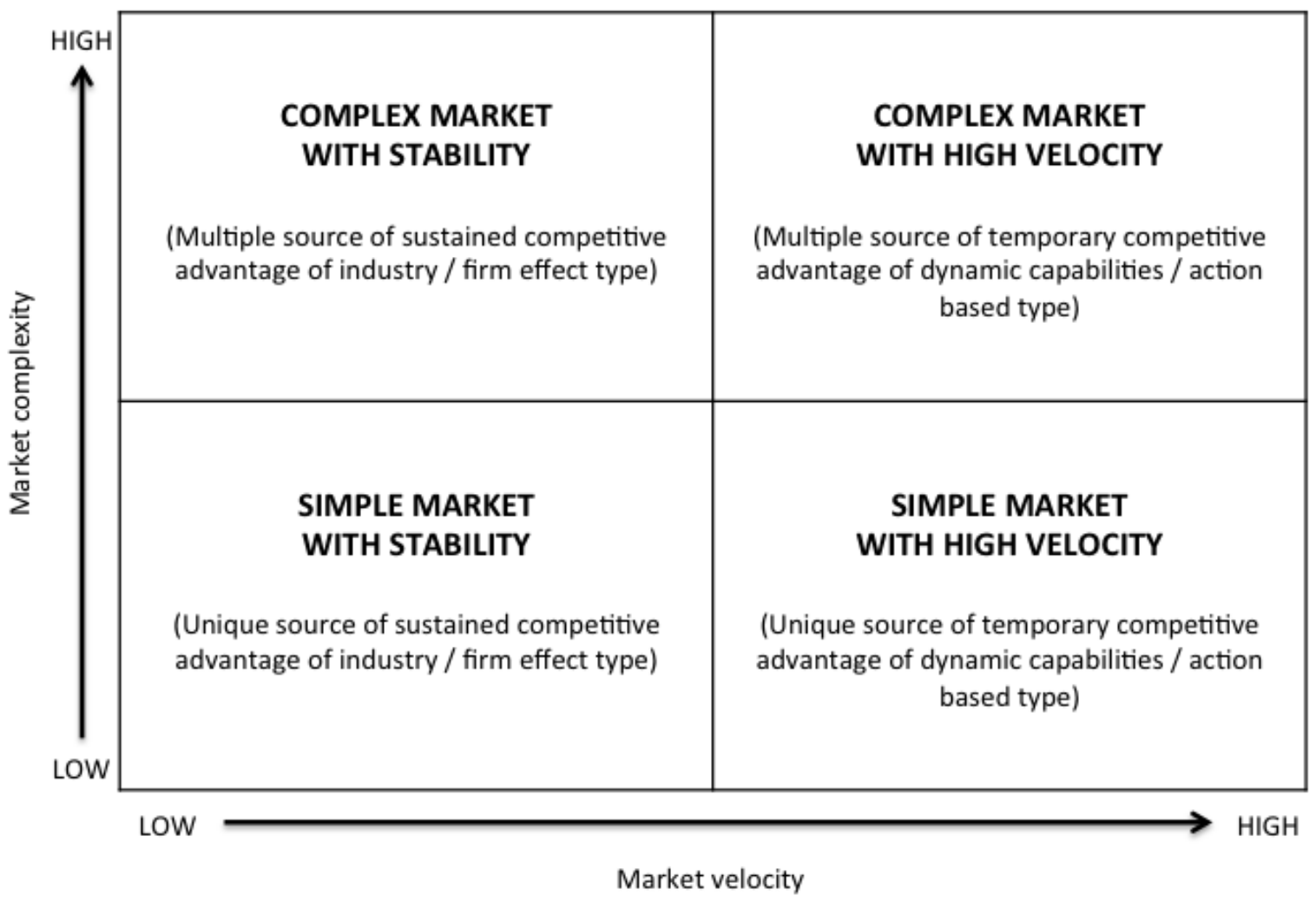

Figure 2-Market competitiveness type, classified by Market complexity and velocity dimensions - Suggested by the author

As market competitiveness in terms of different speeds (see Figure 1) have already been described, the complexity aspects of market competition will be highlighted here. Market complexity is defined as the quantity of rivals, segments, product/service offers, customer set preferences, suppliers and partners that the firm should have to manage in a competitive framework. This is very similar to the view of Chakravarthy, who defined complexity as: "... a measure of the number of competitive configurations that a firm must ideally consider in shaping its own strategy" (Chakravarthy, 1997; pg 69.).

A complex market with a stability situation should be one where the firm has multiple sources of sustained competitive advantage based on industry and resource configuration. Such environments are very similar to the core competency approach where a firm could compete in many markets with many players because it shares a common valuable resources frame that brings at the same time, differentiation and economy of scale, and allows maintenance of superior rent generation in many different markets. (Prahalad \& Hamel, 1990). A 
classical example of this kind of strategy configuration is the one adopted by General Electric (Eisenhardt \& Martin, 2000).

In the other extreme of the matrix, a simple market with high velocity could be characterized by a single source of temporary advantage sustained by the use of dynamic capabilities or by an action-reaction strategy approach. This competitive situation is simple in terms of market elements, but very fast in terms of maneuvering and counter maneuvering (Eisenhardt, 1989). In such situations, markets are characterized by two or three players that are involved in a price war and/or disruptive innovation cycle focused on few products. That should be the case for example when market conditions do not allow diversification strategies.

Finally, the complex market with a high velocity situation is one characterized by multiple sources of temporary competitive advantage sustained by dynamic capabilities or/and by an action-reaction strategy approach. In such a situation, a firm should compete in many different high velocity marketplaces with a variety of different types of products/service offers. This situation should be characterized by the management of a different cycle of concatenate competitive advantage that could have a different speed and frequency of renewal. The firm that competes in such a situation should have a core competency of dynamic capabilities, complemented by local action-reaction strategies.

As the matrix proposed in Figure 2 is a paradigm, it is highly possible to find a composed situation where the firm is involved in many quadrants of the matrix.

It is also important to observe that firm size and maturity should be variable in relation to the degree of market complexity. In fact, to participate in a different marketplace, to compete with a different type and quantity of competitors require a minimum firm's size and maturity level. On the other hand, a firm involved in a simple market situation could be very young and smaller. For this young and small firm, high velocity could be a reality at the very beginning.

\section{TOWARD A MULTIPLE STRATEGIES APPROACH OF COMPETITIVE ADVANTAGE}


In such a situation a firm may have to manage at the same time a mature source of rent generation based on a market position, protected by an economy of scale, or by a reputation, or/and complemented by a set of core resources. As the firm suffered a commoditization effect on its original source of competitive advantage, and lost part of its superior rent generation, the firm's managers could have decided to enter new segments and markets through the introduction of new types of products/services or by establishing new types of alliances, to attain new types of customer or to attend new customer habits. For example, a recent research in the prepackaged software industry, demonstrated that the continuous renewal management of complementary products have been used to sustain competitive advantage (Lee, Venkatraman \& Tanriverdi, 2010).

These new markets/segments could present different levels of competitive intensity and maturity. Some new segments entered are still unexplored by competitors because the speed of imitation process is slow (a stable market situation). Other new segments, besides their youth are intense in competition, as many competitors are trying to reach a leadership position (a high-velocity market situation). In these nascent high dynamic markets, the firm would have to manage a sequence of competitive actions to sustain advantage (Rindova, Ferrier \& Wiltbank, 2010).

Take as an example a grocery and general appliance retail chain. This firm could have different store formats that serve different types of customers, through different channels, offering different types of product and services. This firm could have a large store format with a general purpose in grocery and appliances supply, with a low cost, low price approach. It could also have different neighborhood grocery store formats: one that attends to sophisticated customer demands; which offers high quality/high diversity products assortment and customized services. Another is an express format for quick supply, offering limited products assortment and services, with high location capillarity. Additionally, these stores could be located in very different ethnic/class level neighborhoods, requiring specific products assortment and services.

This firm should also have different types of sales channels such as home delivery and an Internet store.

The original market of this retail firm could be one of its store formats, such as the hypermarket. Because of it, the firm has been sustaining its 
competitive advantage based mainly on an economy of scale industry effect. As the firm developed many different types of store formats with different sizes, product assortment offers and capillarity locations, the firm's managers should have developed a second core source of competitive advantage based on a strategic resources and capabilities of supply chain management (Lowson, 2001). Whereas in the past these two cores have been sufficient to sustain its competitive advantage it could not be the case nowadays, as the increase of competitiveness provoked by new entrants and a change in customer habits could have undermined such sources of advantage. In fact this firm would probably have traditional rivals from past competition. These rivals should be positioned in different segments/markets and offer different sets of values to avoid direct competition. These rivals have also developed around their position sets of unique strategic resources as a second source of competitive advantage. The competition with these traditional rivals is based on economy of scale and efficiency, and segment positioning, to avoid direct and aggressive rivalry situations.

On the other hand, recent entrants, familiar to customer habit changes could bring a new layer of competition intensity. Smaller specialized retail stores, in specific segments or channels, could have confronted this retail firm. For example, a specialized grocery store could explore specific product assortments and service attendances in ethnic neighborhoods. Furthermore, a specialized appliances store could offer an aggressive rivalry through Internet channels, offering a large and wide assortment of variety in a few categories, extensive knowledge of product usability and affordable price on an Internet channel. In conclusion, this retail firm has been competing in very different situations, in very different segments with very distinct competitors. The original competitive advantage sustained by the economy of scale and supply chain resources and managerial best practices, could be partially or totally nullified by these smaller but aggressive competitors due to customer preferences constantly shifting. This type of situation has been referred to as a residual effect of competitive advantage and remains as an unexplored subject in the strategy management literature (D'Aveni, Dagnino \& Snith, 2010).

In such conditions, a hypercompetitive environment may form by a sequence of quick maneuvering and counter maneuvering, as price cuts, promotional offers, and new product introductions. This hypercompetitive 
environment occurs at the store level, as each store locality could present a different competitive configuration and intensity, with a different variety of rivalry in quantity of competitors and type of competition. In such a context, a firm should deploy multiple competitive strategies and manage multiple sources of competitive advantage with different degrees of temporality, erosion and time compression. Multiple competitive strategies could be composed of a different velocity of dynamic capabilities cycles (Helfat \& Peteraf, 2003), each one corresponding to a different market level of competition and maturity.

In a multiple competitive strategies approach, a firm could benefit from sustained competitive advantage balancing and combining different types of sources of competitive advantage. This composition in this higher complexity could be sustained partly by an industry effect, partly by a firm's resources effect, partly by the use of dynamic capabilities or/and action-based advantages characterized by sequences of concatenate temporary competitive advantages. Figure 3 shows an example from a simple strategy approach with a unique source type of competitive advantage compared to a multiple strategy approach with a multiple source type of competitive advantage.

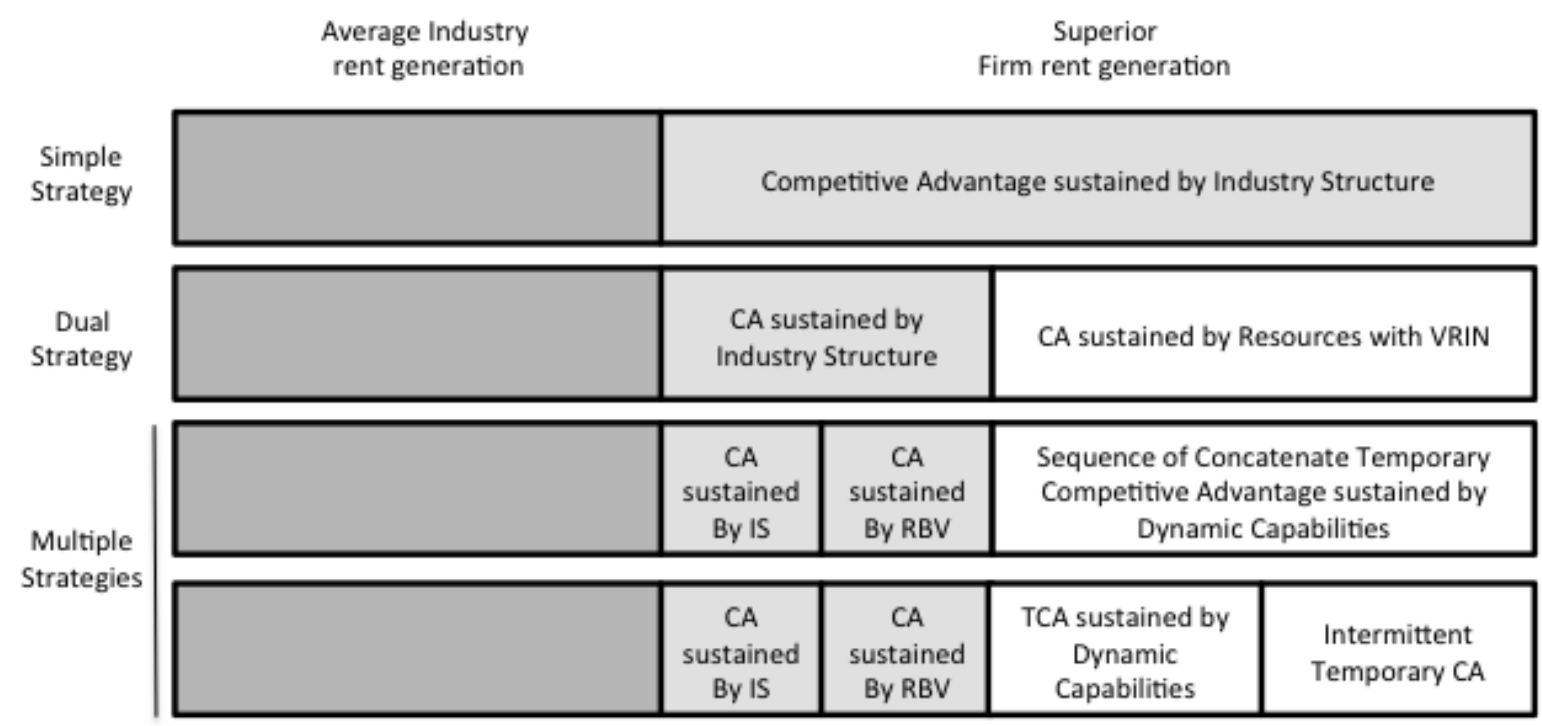

Figure 3 - Degree of composition of competitive advantage by level of strategy complexity Suggested by the author

In this theoretical example, in the first instance, the firm is established in a stable market with low complexity, has sustained its rent generation based on a unique source type of competitive advantage: an industry structure. As the level of rivalry increases and the nature of the market becomes more dynamic, 
the firm suffers a reduction of its superior rent generation, which was reestablished by a second strategy based on Resources. In a third step, that part of superior rent generation sustained by the resource approach, also eroded, and was re-established by a third strategy approach based on dynamic capabilities.

The last situation presents the most complex composition of a type of competitive advantage source, combining industry and resources residual effects, sequence of concatenate temporary advantage and intermittent temporary advantage.

Also, the temporary part of the superior rent sustainability could be composed of sequences of different frequencies and speeds. In fact, as it has already been elucidated, all types of competitive advantage are temporary in nature, and they differ only by the degree of their duration effect. Therefore, the one that lasts for a very long period of time is called sustained competitive advantage. Consequently, a multiple strategies approach should compose competitive advantage of different duration effects and demand a different velocity of replacement. In a hypercompetitive environment, a firm should have to manage these different temporary competitive advantage velocities.

This point of view is in accordance with recent trends and research opportunities raised by D'Aveni, Dagnino and Smith (2010) in the field of strategy and temporary advantage in a recent article. After gathering the main trends of research on temporary competitive advantage, the authors ask if the existence of sustained competitive advantage and temporary advantage are mutually exclusive or could simultaneously co-exist. Additionally, the authors concluded that competing in hypercompetitive environments could not be done only with a unique and simple strategic approach. They defend the adoption of multiple strategic approaches, one for each competitive situation. Below is a transcription of their own words: "Finally, another emerging insight is that firms do not have just one strategy. They may have a multiplicity of strategies - each strategy takes on rivals one at a time. In fact, in a world of temporary advantages, it may be rare to see a firm having just one strategy that universally applies across all rivals. A firm may have as many strategies as it has competitors. Yet the field of strategy still talks about firms as if they had just one strategy".

In fact, some OI traditional scholars long defended the use of generic and unique strategy. The famous Porter (1996) advice to "do not get stuck in the 
middle", is based on the concept of adopting only one positioning strategy, having to choose between a differentiation or cost approach. Miller (1992) and Miller and Friesen (1986) demonstrated that generic strategy and a simple strategy repertoire could be a trap for mature firms. One of the reasons is that firms that experienced in the past success focusing on few assets, competencies and markets, become accommodated and do not develop new capabilities or take the risk to explore new opportunities. At the very time that their market changes to hypercompetition, such firms do not have the correct reaction at the correct time to adapt and change. In addition, Miller (1992) defends that a simple strategy adoption should be easier to imitate by rivals than a more mixed approach and who benefit from a different source of competitive advantage and should be difficult to reproduce.

On the other hand, complex competitive environments should require a more complex strategic approach. For example, the management of multimarket contact through multiple maps of competitive pressure highlights the nature of the complexity of competitive environments (D'Aveni, 2002). Rivkin (2000) demonstrates that a complex strategy approach could be used as a barrier to imitation. In fact, a strategy composed of many parts, which results in many possible combinations should be intractable by an imitator. However, Rivkin (2000) fails to establish a relationship of strategy complexity with a firm's performance, more precisely, the relation of rent generation sustainability. As a complex strategy, it would not necessarily bring superior rent generation, and it may not be necessary to imitate it. On the other hand, in an empirical research, McNamara, Luce and Tompson (2002), demonstrated that firms whose top management teams use more complex strategic group knowledge to take decisions have a better economic performance than others.

\section{ECONOMIES OF EMERGENT COUNTRIES AS CANDIDATES FOR THE STUDY OF COMPLEX COMPETITIVE ENVIRONMENTS}

Markets of developed countries should present the most complex competitive environment in comparison with developed countries that have stable and mature markets, firstly because of their cultural diversities, frequent disruptive economic change and high social contrasts. It is common in an 
emerging economy that a firm should have to lead in a very short cycle, with a high variation of cost due to currency rate volatility, or by disequilibrium between supply and demand related to many social and economical infrastructure investments. In fact, in emergent countries a recent development of economic prosperity with increased demand could lead to a rise in inflation, due to bottlenecks in infrastructure and raw material supplies. Frequent changes in fiscal and business policies, a lake of industrial and national economic long-term strategies, lead to many markets being unpredictable in relation to a firm's longterm investments.

Secondly, because institutional development and competitive regulation have been established, reducing advantage based monopoly and duopoly, leads by consequence to hypercompetition (Hermelo \& Vassolo, 2010). Consequently, emerging economies should present a very interesting context to study as to how firms have been developing their strategy framework to lead in such complex competitive environments. In such environments, the adoption of multiple strategies should lead to the development of new managerial capabilities in order to handle at the same time paradoxical activities, such as the one described by the ambidexterity approach in exploration versus exploitation tasks ( $O^{\prime}$ Reilly \& Tushman, 2004; Simsek, 2009). In fact, a complex and hypercompetitive competitive environment should require balancing, at the same time as an exploitation of current products and service portfolio, but also which is renewable (exploration) to sustain the chain of concatenated temporary advantage. In an emerging economy these strategy management capabilities should lead to a resilience effect of sustained competitive advantage where a successful source of temporary advantage compensates others that have been eroded or did not bring the expected rent. In such a situation, a firm's source of competitive advantage resilience could bring a more persistent competitive advantage. 


\section{CONCLUSION}

In summary, firms have been confronted by an increase of competition. This intensity of rivalry is due in part to the increase of competitors but also because industry structures are much more dynamic in nature, frequently altering the rules of the game, making obsolete market leaders sooner and bringing new entrants. In this literature review, it was clear that stable markets, the ones that offer a stable position with unfailing entry barriers, which permit the firm to find a profitable position and enjoy long-term abnormal returns are rare. On the other hand, it seems that hypercompetitive markets, specifically the ones characterized by high velocity are more common than the exception. This general increase of market dynamics raised the question of the existence of temporary advantage and put in doubt the real existence of the sustainability of competitive advantage. A disruption of epistemological concept has surged, at the same time that the temporal nature of competitive advantage was introduced. In fact, a competitive advantage could not be considered sustainable ad infinitum. Therefore, it is necessary to distinguish degrees of temporality of competitive advantage: ones that last for a long time, others that are much more ephemeral. Traditional strategy approaches based on industry and firm's effects have been losing their advantage as the markets become more dynamic.

In such conditions, new approaches to strategy have been emerging, as dynamic capabilities, new 7's framework and competitive dynamics among many others. It is highly possible that firms have been confronted by diverse competitive realities, as most of them diversified or expanded their operation in new segments and other markets, in search for new sources of competitive advantage. These diverse competitive realities should involve different approaches to be able to lead with sources of competitive advantage and should involve multiple strategies for their management. Finally, a multiple strategy approach could be characterized as a resilient capability, where the management of a diversity of rent generation source, by a compensatory effect, sustains competitive advantage.

In this literature review we raised many research opportunities for further development: Firstly, that research in hypercompetition has been considered only in terms of velocity, and that they have been omitting the complexity aspect 
of competition. This has probably been restricting the research to some particular cases of hypercompetition of high velocity with a low complexity environment. Thus, considering the complexity dimension of a hypercompetitive environment, a firm should have been using a multiple strategies approach to lead with this complexity. Regarding this, we suggested in this article a theoretical framework that combines two dimensions: market complexity and market Velocity with two degree of intensity: high and low. This framework is represented by a matrix of four situations: simple market with stability, simple market with high velocity, complex market with stability, and complex market with high velocity (Figure 2). Clarifying and improving the concept of hypercompetition using the dimension of Market complexity is fundamental to understand the type of competitive configuration that a firm could be confronted. Also that permits to study more precisely, how firms are competing in complex competitive environment and what type of competencies they have been developing. Also, many new research directions could be undertaken from this renewed approach of competition. Particularly, understanding how firms have been combining different types of competitive advantage should be a central research subject. In fact, as we demonstrate in this literature review, due to the turbulent and dynamic nature of nowadays business environments, that should be common to find firms across different degree of Market velocity and complexity. The managerial implication on the strategy definition, organizational structures and resources allocation should be of particular interest. More precisely, future research should investigate what are the managerial practices, competencies, organizational structure that theses firms have been developing to manage multiple sources of competitive advantage in different life cycle and capacity of sustainability and rent generation. Results of theses researches should reveal formal routines and procedures in managing multiple sources of competitive advantage. Also decentralized decision process should be found to allow a fast and efficient renewal of the source of competitive advantage so fundamental for surviving in such dynamic environments. Also, as managing multiple sources of competitive advantage should involve simultaneously explorative and exploitative activities, a relationship should be found with the presence of organizational ambidexterity capabilities. Finally, once the relationship of theses managerial characteristics with high degree of Market complexity and velocity confirmed, further researches should study the relationship of theses managerial characteristics with firm's 
performance, contributions that could be highly valuable and elucidating to the field of competitive strategy.

\section{REFERENCES}

Amit, R. \& Schoemaker, P. (1993). Strategic assets and organizational rent. Strategic Management Journal, 14(1), 33-46.

Bain, J. (1956). Barriers to new competition. Cambridge, MA: Harvard University Press.

Bain, J. (1968). Industrial organization. New York: Wiley.

Barney, J. (1991). Firm resources and sustained competitive advantage. Journal of Management, 17(1), 99-120.

Barney, J. \& Zajac, E. (1994). Competitive organizational behavior: toward an organizationally-based theory of competitive advantage. Strategic Management Journal,15, 5-9.

Black, J. \& Boal, K. (1994). Strategic resources: traits, configurations and paths to sustainable competitive advantage. Strategic Management Journal, 15, 131-148.

Conner, K. (1991). An historical comparison of resource-based theory and five schools of thought within industrial organization economics: do we have a new theory of the firm? Journal of Management, 17(1), 121-154.

Chakravarthy, B. (1997). A new strategy framework for coping with turbulence. Sloan Management Review, 38(2), 69-82.

Diericx, I. \& Cool, K. (1989). Asset stock accumulation and sustainability of competitive advantage. Management Science, 35(12), 1504-1511.

D'Aveni, R. A. (1994). Hypercompetition: managing the dynamics of strategic maneuvering. New York: Free Press.

D'Aveni, R. A. (1999). Strategic supremacy through disruption and dominance. Sloan Management Review, 40(3), 127-135.

D'Aveni, R. A. (2002). Competitive pressure systems mapping and managing multimarket contact. MIT Sloan Management Review, 44(1), 38-49.

D'Aveni, R. A. (2010). Beating the commodity trap. How to maximize your competitive position and increase your pricing power. Boston, MA: Harvard 
Business Press.

D'Aveni, R. A., Dagnino, G. \& Smith, K. (2010). The age of temporary advantage. Strategic Management Journal, 31(13), 1371-1385

Eisenhardt, K. (1989). Making fast strategic decisions in high-velocity environments. Academy of Management Journal, 32(3), 543-576.

Eisenhardt, K. \& Martin, J. (2000). Dynamic capabilities: what are they? Strategic Management Journal, 21, Special Issue, 1105-1121.

Harvey, M., Novicevic, M. \& Kiessling, T. (2001). Hypercompetition and the future of global management in the twenty-first century. Thunderbird International Business Review, 43(5), 599-616.

Helfat, C. E. (2000). Guest editor's introduction to the special issue: the evolution of firm capabilities. Strategic Management Journal, 21(10-11), 955-959.

Helfa, C. E. \& Peteraf, M. A. (2003). The dynamic resource based view: capability life cycles. Strategic Management Journal, 24(10), 997-1010.

Hermelo, F. \& Vassolo, R. (2010). Institutional development and hypercompetition in emerging economies. Strategic Management Journal, 31(13), 1457-1473.

Grant, R. M. (1991). The resource-based theory of competitive advantage: implications for strategy formulation. California Management Review, 33(3), 114-135.

Grimm, C., Lee, H. \& Smith, K. (2006). Strategy as action. New York: Oxford University Press.

King, A. (2007). Disentangling interfirm and intrafirm causal ambiguity: a conceptual model of causal ambiguity and sustainable competitive advantage. Academy of Management Review, 32(1), 156-178.

Lee, C., Venkatraman, N. \& Tanriverdi, H. (2010). Complementarity-based hypercompetition in the software industry: theory and empirical test, 19902002. Strategic Management Journal, 31(13), 1431-1456.

Lengnick-Hall, C. \& Wolff, J. (1999). Similarities and contradictions in the core logic of three strategy research streams. Strategic Management Journal, 20(12), 1109-1132.

Levy, D. (1994). Chaos theory and strategy: theory, application, and managerial implications. Strategic Management Journal, 15, 167-178.

Lippman, S. \& Rumelt, R. (1982). Uncertain imitability: an analysis of interfirm 
differences in efficiency under competition. The Bell Journal of Economics, $13(2), 418-438$.

Lowson, R. (2001). Retail operational strategies in complex supply chains. International Journal of Logistics Management, 12(1), 97-111.

Lumpkin, G. \& Dess, G. (1995). Simplicity as a strategy-making process: the effects of stage of organizational development and environment on performance. Academy of Management Journal, 38(5),1386-1407.

Mason, E. (1939). Price and production policies of large-scale enterprises. American Economic Review, 29(1), 61-74.

Mahoney, J. \& Pandian, R. (1992). The resource-based view within the conversation of strategic management. Strategic Management Journal, 13(5), 363-380.

Miller, D. \& Friesen, P. (1986). Porter's (1980) Generic strategies and performance: an empirical examination with American data. Parte I: Testing Porter. Organization Studies, 7(1), 37-55.

Miller, D. (1992). The generic strategy trap. Journal of Business Strategy, 13(1), 37-41.

Miller, D. (1993). The architecture of simplicity. The Academy of Management Review, 18(1), 116-138.

Miller, D. \& Chen, M. (1996). The simplicity of competitive repertoires: an empirical analysis. Strategic Management Journal, 17(6), 419-439.

McNamara, G., Luce, R. \& Tompson, G. (2002). Examining the effect of complexity in strategic group knowledge structures on a firm's performance. Strategic Management Journal, 23(2), 153-170.

McNamara, G., Vaaler, P. \& Devers, C. (2003). Same as it ever was: the search for evidence of increasing hypercompetition. Strategic Management Journal, 24(3), 261.

O'Reilly, C. \& Tushman, M. (2004). The ambidextrous organization. Harvard Business Review, 82(4), 74-81.

Pacheco de Almeida, G. (2010). Erosion, time compression, and selfdisplacement of leaders in hypercompetitive environments. Strategic Management Journal, 31(13), 1498-1526.

Peteraf, M. (1993). The cornerstones of competitive advantage: a resourcebased view. Strategic Management Journal, 14(3), 179-191. 
Porter, M. (1980). Competitive strategy: techniques for analyzing industries and competitors. New York: Free Press.

Porter, M. (1981). The contributions of industrial organization to strategic management. Academy of Management Review, 6(4), 609-620.

Porter, M. (1985). Competitive advantage: creating and sustaining superior performance. New York: Free Press.

Porter, M. (1990). The competitive advantage of nations. New York: Macmillan.

Porter, M. (1991). Towards a dynamic theory of strategy. Strategic Management Journal, 12(Winter Special Issue), 95-117.

Porter, M. (1996, November-December). What is strategy? Harvard Business Review, 74(6), 61-78.

Prahalad, C. K. \& Hamel, G. (1990). The core competence of the corporation. Harvard Business Review, 68(3), 79-92.

Rindova, V., Ferrier, W. \& Wiltbank, R. (2010). Value from Gestalt: how sequences of competitive actions create advantage for firms in nascent markets. Strategic Management Journal, 31(13), 1474-1497.

Rivkin, J. (2000). Imitation of complex strategies. Management Science, 46(6), 824-844.

Schumpeter, J. A. (1942). Capitalism, socialism and democracy. Cambridge, MA: Harvard University Press.

Simon, H. (1962, December). The architecture of complexity. In Proceedings of the American Philosophic Society, 106(6), 467-482.

Simsek, Z. (2009). Organizational ambidexterity: towards a multilevel understanding. Journal of Management Studies, 46(4), 597-624.

Spanos, Y. \& Lioukas, S. (2001). An examination into the causal logic of rent generation: contrasting Porter's competitive strategy framework and the resource-based perspective. Strategic Management Journal, 22(10), 907934.

Stacey, R. (1995). The science of complexity: an alternative perspective for strategic change processes. Strategic Management Journal, 16(6), 477-495.

Teece, D, Pisano, G. \& Shuen, A. (1997). Dynamic capabilities and strategic management. Strategic Management Journal, 18(7), 509-533.

Wernerfelt, B. (1984). A resource-based view of the firm. Strategic Management Journal, 5(2), 171-180.

Wiggins, R. R. \& Ruefli, T. W. (2005). Schumpeter's ghost: is hypercompetition 
making the best of times shorter? Strategic Management Journal, 26(10), 887-911.

Williams, J. (1992). How sustainable is your competitive advantage? California Management Review, 34(3), 29-51

Winter, G. (2003). Understanding dynamic capabilities. Strategic Management Journal, 24(10), 991-995. 